\title{
Representations of Transnational Human Trafficking: A Critical Review
}

\author{
Christiana Gregoriou and Ilse A. Ras
}

\begin{abstract}
The collection introduction defines human trafficking and proceeds to offer an in-depth literature review that assesses the significance of attention to the collection topic, suggests new directions for research, and provides a synopsis and integrative analysis of the collective contributions of manuscripts within the collection. It starts by detailing the story of human trafficking (the types, causes, and frames of trafficking), then discusses the effects of misrepresentation on the directly affected (draws on victim hierarchy, criminalisation and secondary victimisation), and then deals with the socio-political causes and effects of misrepresentation (gender and wealth inequality, global and local politics, and secondary exploitation). It ends by providing a rationale as to the nature of the case studies the book and its contributors consider.
\end{abstract}

Keywords Criminalisation • Human trafficking • (Mis)representation • Transnational organised crime $\bullet$ Victim hierarchy

C. Gregoriou $(\bowtie) \bullet$ I. A. Ras

School of English, University of Leeds, Leeds, UK e-mail: c.gregoriou@leeds.ac.uk; i.a.ras@leeds.ac.uk

(C) The Author(s) 2018 


\section{INTRODUCTION}

This collection's various studies examine representations of human trafficking (henceforth HT), traffickers, and victims in media ranging from British and Serbian newspapers, British and Scandinavian crime novels, and a documentary series, before questioning the extent to which these portrayals actually reflect the realities of trafficking. We show that media reporting on HT matters, and is impactful; HT victims are idealised, with those not according to this ideal being criminalised. Selected official source aspects of HT take priority over others that are neglected, and hence frame HT in problematic ways. Instead, fictional and factional representations of this crime can be better used as tools with which change in HT victim treatment can be engendered. Our studies focus on news articles, crime fiction, and documentaries published and released post-2000, the year in which the UN Office on Drugs and Crime Protocol to the Convention on Transnational Organised Crime, on trafficking (nicknamed the Palermo Protocol), was passed, and covers a time period in which the Modern Slavery Act 2015 was passed and the refugee and migrant crisis spread across Europe. Whilst we primarily focus on British news, fiction, and documentaries, we have also included Scandinavian crime fiction and Serbian news to facilitate comparisons with, respectively, a literary tradition that focuses on social realist themes (Brunsdale, 2016), and news from a country affected by trafficking in three dimensions (origin, transfer, and destination) and on the route of refugees from Syria, Afghanistan, and Iraq (European Commission, 2017).

We adopt the definition of trafficking set out in the Anti-Slavery International RACE Project report on 'Trafficking for Forced Criminal Activities and Begging in Europe' (2014, p. 86):

Trafficking involves bringing people away from the communities in which they live and forcing them into work against their will using violence, deception or coercion. When children are trafficked, no violence, deception or coercion needs to be involved: simply transporting them into exploitative conditions constitutes trafficking.

This definition follows the UN (Palermo) Protocol to Prevent, Suppress and Punish Trafficking in Persons Especially Women and Children, supplementing the United Nations Convention against Transnational Organized Crime (UNODC, 2016, passed in 2000). We acknowledge that this definition is problematic, as its terms are difficult to define, and it 
is difficult to establish where the thresholds of the lack of consent, and the level of deception, exploitation, coercion, and movement are located.

Previous research on the representations of HT shows that these narratives are often overly focused on only one form of HT and one particular type of victim, with the highly damaging effect of ignoring or even criminalising (other) victims of other types of HT. As such, we are critical of representations that serve to limit those forms of exploitation, force, deception, or movement, that are considered 'proper' forms of HT, and that serve to distinguish between 'real' and 'unreal' victims of HT. We argue that the characteristics of the HT narrative sustain the global structures that make people vulnerable to being trafficked in the first place. These include gender and wealth inequality, and the geopolitical power balance that primarily benefits the global West.

This introductory chapter first examines the commonly accepted definitions and narratives of HT, as found in previous studies. It then traces the effects of these stories on those vulnerable people who are trafficked, or smuggled and exploited at their destinations. Finally, it considers the global inequalities that are perpetuated by these narratives, before this collection's chapters are outlined.

\section{The Story and Truth(s) of Human Trafficking}

Media representations inform public and practitioners as to the nature of HT: they are seen and referenced by policymakers and therefore shape discourse on HT (Small, 2012). The increasing 'celebritisation' of the problem, with the rise of celebrity activists as rescuers, 'ambassadors', and (often ill-informed) 'experts', also signals pop culture's powerful role in anti-trafficking movements (Haynes, 2014, cited in Kinney, 2015, p. 90; see also Steele, 2015). Wylie (2016) traces the rise of a particular version of the story of human trafficking, and its adoption into 'common knowledge', drawing on the concept of the norm lifecycle in International Relations (Finnemore \& Sikkink, 1998, in Wylie, 2016). In this lifecycle, a norm is first campaigned for by moral entrepreneurs, then supported by global actors (ibid.). If enough global actors support the new norm, others are pushed to accept it also (ibid.). The norm is then enacted on local levels, and finally becomes 'common knowledge' (ibid.). Wylie (2016) points out that the norm only successfully completes this lifecycle if it is in line with pre-existing norms, and can be used to support the material and immaterial interests of global and local actors. 
Wylie (2016, p. 2) notes that in the past 20 years, a particular version of the human trafficking story has become the new normal. Winterdyk, Reichel, and Perrin $(2012$, p. 9) indicate that the first decade of the twenty-first century met with 'an explosion of media coverage' of HT, which they partially attribute to the passing of the Palermo Protocol in 2000. Wylie (2016) instead identifies the Palermo Protocol as part of the lifecycle. This increase in reporting would, initially, appear to be a positive development, as the public's and (untrained) practitioners' understanding of what HT is, and who the victims are, is dependent on media representations (De Shalit, Heynen, \& Van der Meulen, 2014; Denton, 2010; Farrell \& Fahy, 2009; Papadouka, Evangelopoulos, \& Ignatow, 2016; Sanford, Martínez, \& Weitzer, 2016; Sobel, 2016). Problematically, however, the 'master' narrative of HT (Snajdr, 2013; see also Wilson \& O’Brien, 2016), or the version of the story of human trafficking that has become the new normal (Wylie, 2016), is full of, and based on, unreliable statistics, maps, and visual images, and selective, binary, and simplified representations (ibid.). The RACE Project report suggests that most HT cases go unreported in the media, but even when they are reported, they are often devoid of details such as nationality, age, outcome/sentence length of those convicted, and indicators of trafficking (e.g., confinement, passport loss, and no or minimal pay).

\section{Simplification}

The difficulty in representing HT accurately is illustrated by the misuse of labels such as 'trafficking' and 'smuggling'. Legally, the former is a crime against an individual and can be intranational, while the latter is a crime against the state and is, necessarily, transnational. Unlike trafficking, smuggling is presumed to be consensual on the part of the smuggled (Lobasz, 2009 , p. 328). The reality of trafficking/smuggling is not quite so clear. ' $[\mathrm{S}]$ ome argue that human trafficking and migrant smuggling are better thought of as two ends of a continuum' (Lobasz, 2009, p. 328), the concepts being 'intricately intertwined' (Aronowitz, 2009, p. 4). Consent may be blurry or absent at various stages of either process. Both those trafficked and those smuggled are susceptible to exploitation (O'Connell Davidson, 2010, p. 249; Piper, Segrave, \& Napier-Moore, 2015). Those who have been smuggled and are exploited later are, legally, victims of trafficking, even if, at the border, they are considered as having been smuggled (Kara, 2010, p. 189; Lobasz, 2009, p. 328; Wylie, 2016, p. 6). 
Kelly (2005) indicates that the length of the journey increases the probability that a person is coerced or deceived, as well as exploited, as longer journeys increase people's vulnerability. Exploitation may also be done by people other than the smugglers, due to the undocumented status of those smuggled (Wylie, 2016, p. 6). This interconnection might explain why the media and the public tend to conflate the two (Dando, Walsh, \& Brierley, 2016; Denton, 2010; Farrell \& Fahy, 2009; Marchionni, 2012; Papadouka et al., 2016; Winterdyk et al., 2012).

The problem does not just lie with the media conflating the two concepts, but with how the distinction is made. Male irregular migrants are generally presumed smuggled, thus presumed as having consented to their movement, whereas female irregular migrants are generally presumed trafficked, as not having consented to movement (De Shalit et al., 2014; Musto, 2009). As a result, the (male) smuggled migrant is criminalised, whilst the (female) trafficked migrant is assigned victim-status (Hua \& Nigorizawa, 2010, pp. 406-407). The differentiation between trafficked and smuggled migrant may also depend on whether they are perceived as having been 'exploited enough', creating a distinction between 'deserving' and 'undeserving' migrants (Wylie, 2016, p. 6). This distinction also distracts from the fact that both smuggled and trafficked people are often vulnerable, escaping a local environment plagued by poverty, conflict, disaster, or all of the above, searching, despite the many risks involved, for a better place in which to live and work.

\section{Types of Trafficking}

The Palermo Protocol refers to all forms of labour as potential forms of exploitation (De Shalit et al., 2014, p. 392), even though it privileges sex trafficking (Wylie, 2016). Throughout media representations, the focus tends to be on sex trafficking (Alvarez \& Alessi, 2012; Buckley, 2009; Denton, 2010; Dijk, 2013; Farrell \& Fahy, 2009; Kelly, 2005; Lobasz, 2009; Marchionni, 2012; Moore \& Goldberg, 2015; Papadouka et al., 2016; Segrave, 2009; Wylie, 2016; Yick, 2010), an assessment statistically supported by Marchionni's (2012) classification of the types of trafficking normally reported:

- Sex: $51.5 \%$

- Labour: $4.1 \%$

- Domestic: $2.3 \%$ 
- Other: $9.4 \%$

- Several: $4.9 \%$

- Non-specific: $27.8 \%$

Academic work on trafficking is similarly skewed toward analyses of discourses on the sexual exploitation of women (Duong, 2014), a focus that Szörényi and Eate (2014) attribute to sex trafficking being easily sensationalised. Lobasz (2009) similarly claims that sex trafficking is a 'sexy' topic. This focus on sex is particularly problematic when it results in the underrepresentation of other forms of HT.

In reality, most victims are trafficked for labour exploitation (O'Brien, 2016, p. 210; Feingold, 2005), and HT mainly exists in highly labourintensive, insecure industries, such as agriculture and the gig-economy (Alvarez \& Alessi, 2012; Coghlan \& Wylie, 2011; Kara, 2010; Kelly, 2005; O'Brien, 2016). Trafficking for domestic services also receives little attention. Given its domestic nature, it is difficult to estimate how much such trafficking actually takes place (Kelly, 2005). Other underreported forms of trafficking include fraudulent marriages, illegal adoption, and pregnancy surrogacy (Duong, 2014).

\section{Victims and Traffickers}

The stereotypical global victim of trafficking is '[a] young, naïe woman who seeks a better life away from her rural home by answering an advertisement to become a waitress or a nanny and then ends up a sex slave, repeatedly raped, brutalised, and resold to other mafia pimps' (Lobasz, 2009, p. 340): she is female (Alvarez \& Alessi, 2012; Andrijasevic \& Mai, 2016; Columb, 2015; De Shalit et al., 2014; de Villiers, 2016; Dijk, 2013; Duong, 2014; Farrell \& Fahy, 2009; Hall, 2015; Johnston, Friedman, \& Sobel, 2015; Lobasz, 2009; O’Brien, 2016; Pajnik, 2010; Plambech, 2016; Russell, 2014; Sanchez, 2016; Sanford et al., 2016; Sharma, 2005; Small, 2012; Sobel, 2016; Szörényi \& Eate, 2014; Wilson \& O’Brien, 2016; Yick, 2010), young (Andrijasevic \& Mai, 2016; de Villiers, 2016; Dijk, 2013; Farrell \& Fahy, 2009; Hall, 2015; Hua \& Nigorizawa, 2010; Johnston et al., 2015; Kara, 2010; Lobasz, 2009; O'Brien, 2016; Sanchez, 2016; Sanford et al., 2016; Small, 2012; Szörényi \& Eate, 2014; Wilson \& O'Brien, 2016; Yick, 2010), and unwilling to perform the work she is doing, but coerced (Andrijasevic \& Mai, 2016; Farrell \& Fahy, 2009; Lobasz, 2009; O’Brien, 2016; Sanchez, 2016). Alternatively, children 
may be identified as victims (Alvarez \& Alessi, 2012; Johnston et al., 2015; Plambech, 2016; Sanford et al., 2016; Sharma, 2005; Sobel, 2014; Wilson \& O'Brien, 2016); they too are portrayed as weak/vulnerable, and generally presumed blameless/trafficked against their will. Further to being common in news media and pop culture, these stereotypes are also shared by policy makers and the public (Buckley, 2009; Dando et al., 2016; Gould, 2010; Musto, 2009). Even more so, these characteristics are also consistent with Christie's (1986) 'ideal victim'.

One can argue that the focus on women and children as victims reflects reality; official figures do indicate that it is women and children that are most often labelled as trafficked, presumably due to the focus on sex trafficking (Cunningham \& DeMarni Cromer, 2016; Dijk, 2013; Duong, 2014; Marchionni, 2012, Musto, 2009). Males, more often trafficked for labour exploitation, tend to be considered as having been 'smuggled', rather than 'trafficked', and tend to be classified as (illegal) labour migrants, rather than as victims of HT (Lobasz, 2009, p. 339). Wylie (2016, p. 5) similarly points out that many different people and institutions contribute to these figures, and each contribution is filtered through idiosyncratic understandings of what trafficking is, and who can be trafficked. Either way, men are seldom considered as victims, meaning that male victims are generally overlooked (Alvarez \& Alessi, 2012; Duong, 2014; Sharma, 2005). In fact, under Thai law, it has been assumed that men cannot be victims of trafficking (Feingold, 2005).

The trafficker, in the meanwhile, is painted as 'big and bad', a shadowy, mysterious, powerful figure, often male (De Shalit et al., 2014; de Villiers, 2016; Hua \& Nigorizawa, 2010; Lobasz, 2009; Moore \& Goldberg, 2015; O'Brien, 2016; Pajnik, 2010; Plambech, 2016; Sanford et al., 2016; Sobel, 2016; Wilson \& O'Brien, 2016; Yick, 2010), with generally no mention of whether the victim and trafficker had any prior relation. The offender is simply established as the polar opposite of the victim (Szörényi \& Eate, 2014), even though in reality, this distinction may be unclear. There are indicators that a substantial number of traffickers have previously been trafficked (De Shalit et al., 2014; Moore \& Goldberg, 2015). Lastly, 'Johns', or the consumers of sex work, are only occasionally mentioned (O'Brien, 2016; Sobel, 2016), only occasionally held responsible for sex trafficking, and are generally identified as male (Kara, 2010; Moore \& Goldberg, 2015; Sanchez, 2016). 


\section{Causes of Trafficking}

In media reporting and legislation, structural causes that leave people vulnerable to being trafficked as well as smuggled are systematically ignored (Coghlan \& Wylie, 2011; Johnston et al., 2015; O'Brien, 2016; Piper et al., 2015; Sanford et al., 2016; Sharma, 2005; Steele, 2015; Szörényi \& Eate, 2014; Weitzer, 2007; Wilson \& O'Brien, 2016). Wilson and O'Brien $(2016$, pp. 33, 40) argue that the US Annual Trafficking in Persons Report reinforces 'the representation of human trafficking as a criminal justice issue, constructing victims as passive agents of the criminal behaviour of offenders', 'as opposed to [treating HT as] an economic and political human rights issue'. Officials prefer to focus on the individuals that are directly involved than on structural causes (see also Wylie, 2016).

Structural push factors include local poverty (Duong, 2014; Farrell \& Fahy, 2009; Feingold, 2005; Howard, 2012; Kara, 2010; Kelly, 2005; Moore \& Goldberg, 2015; Sharma, 2005; Sobel, 2014), gender and economic inequality (Avendaño \& Fanning, 2013; Columb, 2015; Farrell \& Fahy, 2009; Hoefinger, 2016; Howard, 2012; Hua \& Nigorizawa, 2010; Kara, 2010; Kelly, 2005; Moore \& Goldberg, 2015; Sobel, 2014), globalisation (Avendaño \& Fanning, 2013; Hoefinger, 2016; Segrave, 2009; Sharma, 2005), conflicts and violence (Feingold, 2005; Kelly, 2005; Limoncelli, 2009; Sharma, 2005) and the difficulty in obtaining work permits, which leaves migrant workers vulnerable to exploitation (Limoncelli, 2009; Moore \& Goldberg, 2015).

Similarly, there is little attention, in both the media and legislation, to pull factors, including the global demand for cheap labour (Avendaño \& Fanning, 2013; Duong, 2014; Feingold, 2005; Kelly, 2005; Kara, 2010; Limoncelli, 2009; O'Brien, 2016; Segrave, 2009; Sharma, 2005) and cheap sex (Kara, 2010; Limoncelli, 2009; Moore \& Goldberg, 2015; Russell, 2014; Segrave, 2009; Sharma, 2005). Even in academic research on trafficking, 'demand' is often only addressed almost incidentally, with a few notable exceptions (see Kara, 2010).

\section{Framing}

The reasons given as to why HT must be addressed change in line with changing political priorities. Farrell and Fahy (2009) show that historically, at least in the USA, HT was framed as a woman's rights issue, ostensibly aiming to protect women, though more likely aiming to keep women 
docile and at home. More recently, HT has been re-framed as a criminal issue, with the result that the USA has passed various laws aimed at criminalising traffickers (and indeed some victims). Post-9/11, the issue has been re-framed again, now as a matter of national security. US policies changed correspondingly, aiming to secure borders, thereby actually increasing the vulnerability of both victims of trafficking and irregular migrants. Marchionni (2012) found that in Britain, HT has become part of discourses about policing and border control.

As Hua and Nigorizawa $(2010$, p. 402) put it, official discourses on trafficking

create a dominant narrative of victimization that helps define who is 'genuinely' trafficked (and who is not). These dominant narratives rely on and reproduce troubling gender-race-nation discourses of victimization, which construct a stereotype of the 'helpless victim' that links femininity to dependency and racial 'otherness' to cultural deviancy.

In general, victims are portrayed as helpless and trapped. Meanwhile, nation states and state-sanctioned (male) actors responding to threats within their borders are set up as 'saviours' (De Shalit et al., 2014; de Villiers, 2016; Hill, 2016; Hua \& Nigorizawa, 2010; Krsmanovic, 2016; O’Brien, 2016; Pajnik, 2010; Russell, 2014; Szörényi \& Eate, 2014; Van der Pijl, Oude Breuil, \& Siegel, 2011).

The effect of this dominant narrative is not just that the sex trafficking of young females is prioritised above all others, although that is in itself an issue. More problematically, it harms those victims who do not conform to these stereotypes.

\section{Effects of Misrepresentation on the Directly}

\section{AfFECTED}

The misrepresentation of HT means that many cases of trafficking are not recognised as such by the public (see Dando et al., 2016). The prioritisation of sex trafficking means that issues such as labour exploitation are pushed to the background (Duong, 2014; Farrell \& Fahy, 2009; Lobasz, 2009; Mendel \& Sharapov, 2016, p. 674; Wilson \& O'Brien, 2016, p. 41), both in terms of media attention and in terms of policy. Even more concerningly, the representation of victims creates a victim hierarchy, resulting in many non-ideal, but real, victims being denied services and 
rights, to the extent where they are prosecuted (Alvarez \& Alessi, 2012; Chuang, 2015; Coghlan \& Wylie, 2011; Cunningham \& DeMarni Cromer, 2016; Farrell \& Fahy, 2009; Feingold, 2005; McAdam, 2013; Meshkovska, Mickovski, Bos, \& Siegel, 2016; Piper et al., 2015; Sanford et al., 2016; Segrave, 2009; Sharma, 2005; Stepnitz, 2012; Szörényi \& Eate, 2014; Wijers, 2015; Wilson \& O'Brien, 2016, p. 41). In fact, Kelly $(2005$, p. 243$)$ estimates that only half of those who need assistance actually receive it.

\section{The Victim Hievarchy}

The problem of this stereotyping is that it creates a scale against which the affected are measured. As a result, even when recognised as victims, nonor less-ideal, but no less real ones, are either offered less support, or denied any altogether. Individuals denied victimhood include those victims trafficked by people they know, which in reality includes a sizeable proportion of total victims (Marchionni, 2012; Sharma, 2005).

One requirement is for the victim to have done nothing that can be considered as having contributed to their being trafficked. This means that if one wishes to be seen as a victim, one must deny all agency. Once a person is a designated 'victim', their agency is also not acknowledged in subsequent proceedings, as victims are presumed unable to speak for themselves (De Shalit et al., 2014; Dijk, 2013; Sobel, 2016). Even more so, the characteristic of lacking agency and having victim-status are circular; Alvarez and Alessi (2012), Chuang (2015), and Columb (2015) suggest that the victim-status itself implies a lack of agency, while the (assumed) lack of agency facilitates victim-status.

Particularly problematic is the gendered interpretation of who can and cannot consent to their movement and exploitation, which relates to the gendered assumption of who can and cannot be deemed a victim, and is not unrelated to cultural constructions of men as active and women as passive (see Marchionni, 2012; Wylie, 2016): women are constructed as victims of male sexual violence (Hua \& Nigorizawa, 2010).

\section{Criminalisation}

Those who fail to qualify as victims are not just denied support and sympathy. They are often criminalised, even though Aronowitz's (2009, p. xii) exposition highlights the need to approach all trafficked/smuggled people 
as the victims they are. Stigmatisation and criminalisation occur both informally and formally.

Informally, socially, many less-ideal victims find themselves blamed for their own victimisation, stigmatised, and even ostracised. Such responses are relatively constant across nations. Buckley (2009) indicates that previous research on Russian responses to victims of trafficking indicates that these victims are rejected by their families and communities. Cunningham and DeMarni Cromer (2016) show that US males also tend to blame victims. In Krsmanovic's (2016, pp. 159-160) article engaging with Serbian newspaper texts about sex trafficking, photography serves to simplify the matter of trafficking and dehumanise, even blame the victim, either for her naiveté, or her willing engagement in the sex industry. Even when the victim is not explicitly blamed, Sobel (2016) suggests that by not mentioning the trafficker, victims are implicitly held responsible for their victimisation.

Formal responses often go beyond simple victim-blaming. For instance, the US Trafficking and Violence Protection Act (TVPA) distinguishes between 'good' victims (of trafficking), and 'bad' victims (of smuggling). As a result of this Act, the voluntarily smuggled worker is criminalised, whereas the supposedly involuntarily trafficked slave is considered a victim (Hua \& Nigorizawa, 2010, pp. 406-407), despite the fact that many smuggled workers end up exploited upon arrival, and are often deceived or coerced into this exploitation (meaning that, legally, they become victims of trafficking). As Hua and Nigorizawa (2010, p. 407) put it:

Trafficking cases $[\ldots]$ may involve many potential victims, but only those who are able to prove their authenticity by fitting into pre-existing assumptions tied to the category 'trafficked victim' are officially granted victim status. Similar to other immigration practices, the TVPA continues in a tradition where 'worthy victims' are sorted from complicit and therefore illegal immigrants.

Columb (2015) shows that organ donors who are not recognised as organ trafficking victims are criminalised by the international protocols on the organ trade. In one case, the judges acknowledged the victim's exploitation and even note 'the suspect had been trafficked', but sentenced them regardless (Anti-Slavery International, 2014, p. 30). Generally, people who have, whether voluntarily or involuntarily, been moved across borders are, if not recognised as victims of trafficking, branded illegal migrants, and as a result criminalised. 
As the Anti-Slavery International (2014) report also suggests, misidentifying victims as offenders not only generates secondary victimisation and vulnerability (with victims having a criminal record and being at an increased risk of going 'missing', deportation, and re-trafficking). It also generates fear of the authorities, reducing the victim's cooperativeness and assistance with further investigations. Criminalisation often has the effect of making victims' situations more precarious by putting them at risk of arrest and prosecution, enhancing exploiters' and traffickers' hold over them (Feingold, 2005; Kelly, 2005; Sharma, 2005; Weitzer, 2007).

\section{Secondary Victimisation}

Even if the victim is successfully recognised as such, and even if practitioners are suitably trained and sufficiently supportive during their 'rescue', many legal systems entail (unintentional) secondary victimisation. For instance, police raids of sex workplaces are violent, traumatising events, harming possible survivors of sex trafficking through interrogation, detention, prosecution, and deportation (Hill, 2016, p. 46). Where sex workers are being 'rescued' by police, '[f]orce, it seems, has become protection, just as war became peace, slavery freedom and ignorance strength, in George Orwell's 1984' (O’Connell Davidson, 2015, p. 205).

Further secondary victimisation occurs after the 'rescue', during the investigation and prosecution, by forcing witnesses and victims to re-live traumatic experiences through repeated interview/interrogation and testifying in court (Meshkovska et al., 2016; Wijers, 2015). Police and judges are often insufficiently trained to understand and respond to the primary trauma suffered by victims (Dijk, 2013; Meshkovska et al., 2016), leading to (unintentionally) harmful practices. The burden of proof is on the prosecuting party, meaning that victims' testimony is put under thorough scrutiny by the defending party (Meshkovska et al., 2016). Criminal proceedings may take years (Meshkovska et al., 2016), during which the victim lives in a state of uncertainty about their legal (immigration) status, and they do not automatically receive compensation from those successfully prosecuted as traffickers. In fact, in order to receive compensation, the victim would have to initiate civil proceedings, which entails another long and arduous legal process (Meshkovska et al., 2016).

Regardless of whether a victim is successfully recognised as a victim and is successfully used by the state in prosecuting traffickers, state responses often include repatriation (Dijk, 2013; Wijers, 2015). This often puts vic- 
tims in the same situation they (were) moved from in the first place (Feingold, 2005), but with additional stigma and possible debt (Kelly, 2005), thereby increasing their vulnerability and the likelihood of their being re-trafficked.

\section{Socio-Political Causes and Effects of MisRepresentation}

The modern slavery narrative is simplistic and fairy-tale-like, a narrative of good and bad. While simplifying complex events is essential in raising the news value of a story (Galtung \& Ruge, 1965; Jewkes, 2011), the harmful effects are numerous. As the earlier section shows, many truly affected persons are, as a result of the victimhood-threshold sustained by the narrative, not offered sufficient support. Wylie (2016) describes in much detail the interests of both global and local parties in adopting and perpetuating this oversimplified and misdirected narrative, which include material power, soft power, and a perpetuation of other norms such as those relating to gender/sex.

\section{The Focus on Female Victims and Sex Trafficking}

The HT narrative sustains gender inequality by perpetuating the myth that men act and women are acted upon (Sobel, 2016; Szörényi \& Eate, 2014; Wylie, 2016). Women are vulnerable, naïve victims, who must be saved by heroic (male) saviours. This gender bias can be traced back to the historical 'white slavery' campaign (Farrell \& Fahy, 2009; Krsmanovic, 2016; Lobasz, 2009) and to cultural attitudes toward female empowerment and sexuality (Attwood, 2016; Hall, 2015; Szörényi \& Eate, 2014).

Those parts of the story that are most illustrative of these sexist attitudes focus on female victims of sexual exploitation. Not only does this focus reiterate the notion that victims are primarily female, that is, women are acted upon, but it is also indicative of a male gaze, whereby women's bodies are objectified as instruments of (male) sexual thrill, not just directly through the sexual abuse of these bodies, but also through the titillating reporting of this abuse.

Through this narrative, it is suggested that the safest place for a woman is to remain at home and to not undertake any supposed risky activities in the pursuit of a better future. This is also evident in counter-trafficking campaigns' exaggeration of the perils of migration, which indeed 'advo- 
cate the private sphere as the safest location for [particularly] women' (Andrijasevic, 2007, p. 41). These narratives are reminiscent of children's literature, where 'home' is seen as the place where we ought to stay or come back to, as opposed to adult literature which sees home as the place we must escape or grow away from (see Clausen 1982, p. 142).

Female migrants are not the only ones held back by this narrative. While female migrants are perceived as trafficked, subsequently stigmatised, and often deported after being used to prosecute their traffickers, male migrants are either perceived as traffickers, or as voluntarily smuggled, criminalised, and then similarly deported after prosecution.

\section{The Lack of Focus on Labour Trafficking and Domestic Trafficking}

The needs of victims (both of trafficking and of global inequality) are secondary to the needs of those with vested interests in maintaining a status quo (Segrave, 2009), such as the ready supply of cheap, exploitable labour. (Western) individuals and states benefit from the current narrative of HT, which glosses over the topic of labour exploitation by focusing on sex trafficking instead (Wylie, 2016). Labour trafficking enables the exploitation of the global poor, which results in lower prices (Szörényi, 2016). There is a general lack of attention to consumers demanding cheap products, thereby increasing demand for cheap labour (Kara, 2010; Mendel \& Sharapov, 2016; O'Brien, 2016).

Global wealth inequality is one of the main structural causes of trafficking. Globalisation has led to global wealth and inequality having become more visible, meaning that the desire to migrate has also increased (Russell, 2014 , p. 537). As migrants have relatively few options, they often have no choice but to engage in exploitative labour in order to survive (Lewis \& Waite, 2015, p. 3). Indeed, many HT victims are undocumented migrants (Lobasz, 2009, p. 327). In other words, the current version of the story of human trafficking is used to justify policing the (transnational) movement of the dispossessed when politically expedient (Sharma, 2005), but simultaneously glosses over those forms of trafficking that serve Western interests (Wylie, 2016).

Addressing gender inequality is politically and ideologically difficult, as is also evidenced by broader ongoing struggles for gender equality. Similarly, relieving poverty and insecurity of those people at risk of trafficking and smuggling would result in a more empowered and less desperate 
workforce, which would diminish global inequality. In turn, many currently powerful parties, both as nations and as individuals, would lose their ability to exploit this workforce.

\section{Global and Local Politics (as Cause and Effect)}

In both the USA and the UK, the anti-HT discourse constructs trafficking as an imported problem and often criminalises all transnational movement except of the most 'worthy' (Sharma, 2005; Andrijasevic, 2007, p. 43; Wylie, 2016), legitimising strict border control and migration policies (Wylie, 2016). However, Kara (2010, p. 117) warns that creating tougher laws pushes trafficking and smuggling further underground, increasing victim vulnerability. At the same time, 'tough' border control and migration policies are seen as vote winning, as is also evident in the popularity of border control television programmes (Szörényi, 2016, p. 86). Wylie (2016) traces the popularity of border control to the need for national governments to signal control in a globalising and globalised world.

Furthermore, the characterisation of trafficking as a foreign and imported problem distracts from the fact that many local causes of trafficking (e.g., poverty, conflict) are the result of the foreign policies of countries such as the USA and the UK. Through foreign policies specifically aimed at 'combating' trafficking, such as the USA's TVPA, these nations are able to maintain the illusion of being 'the good guys' (Wylie, 2016). In awareness campaigns, too, developed nations are positioned as the 'powerful saviour, rather than recognising any impact that developed economies may have in causing or perpetuating systems of global inequality' (O'Brien, 2016, p. 216; see also Pajnik's 2010 media framing analysis' similar finding). As Wilson and O'Brien (2016, p. 42) put it,

[t]hrough constructing the victims of human trafficking as entirely passive actors that lack rational agency, states can position themselves as patriarchal protectors of the weak and innocent, thereby expanding their internal and external policing powers [which] allows wealthy states to maintain the global imbalance of economic and political capital, as human migration from impoverished states to wealthy states is conflated with human trafficking via a fantastical narrative of deception and exploitation. 
Rather than addressing their responsibilities in terms of re-evaluating damaging foreign policies, these nations focus on the type of symptom control that appears well-intentioned. Ultimately, this focus results in the re-victimisation of affected people, while this re-victimisation results in perpetuating the inequalities from which these nations benefit. In other words, other versions of the story of human trafficking, that would perhaps focus more on labour trafficking, might result in the examination of the global socio-economic and political inequalities and the supply of cheap (er) labour that benefits these countries, which would be contrary to their interests. It is, indeed, also these states that most intensely reproduce and police the currently dominant version of the story of human trafficking.

Perhaps the most powerful tool in actually maintaining this story, and thereby economic and gender inequalities, is the USA's Trafficking Victims Protection Act (see Wylie, 2016). The TVPA is used to award, and penalise, nations and NGOs who either support and follow, or fail to follow, the USA's conception of what trafficking entails, and which measures are supposed to be taken to fight it (Cojocaru, 2016; Dijk, 2013; Hua \& Nigorizawa, 2010; Small, 2012; Snajdr, 2013; Weitzer, 2007; Wilson \& O'Brien, 2016). A number of analysts (Cojocaru, 2016; Farrell \& Fahy, 2009; Hall, 2015; Lobasz, 2009; Marchionni, 2012; O’Brien, 2016; Small, 2012; Weitzer, 2007) state that the TVPA in turn is influenced by what they argue is the alliance between certain right-wing Christian groups and conservative-abolitionist feminist groups, and that this alliance is based on a consideration that all sex work is inherently problematic. Wylie (2016) indeed traces the current version of the story of HT, which focuses on sex trafficking of women and children, to the activism of this unlikely alliance united in the pursuit of the abolition of prostitution. The USA use their economic power to impose, narrowly, their narrative of HT, and broadly, a gender-related ideology, upon other actors (Wylie, 2016). A vivid example is Howard's (2012) ethnographic case study of trafficking in Benin. Though acknowledging that global economic inequality is an important trafficking structural factor in trafficking, addressing it would mean that local NGOs would lose their US (-backed) funding, and Benin would suffer politically (Howard, 2012).

In short, the story of HT has political use. The 'heroism' of 'saviours' identifies certain states, such as the USA, as the 'good guys', legitimated by their pursuit of alleviating the 'plight' of certain 'victims', conveniently glossing over the structural and global factors that put certain populations 
at a higher risk of exploitation than others (Alvarez \& Alessi, 2012; Johnston et al., 2015; Szörényi \& Eate, 2014; Weitzer, 2007; Wylie, 2016) and maintaining the economic benefits of having an exploitable, dispossessed workforce that can be policed when it is politically expedient to do so.

\section{Secondary Exploitation}

(Western) nations, consumers and employers are not the only ones benefiting from perpetuating the factors that put people at risk of trafficking. Wylie (2016, pp. 7-9) describes the vast range of institutions that have been tasked, or have tasked themselves, with responding to human trafficking. These exist on levels varying from the local to the supra-national, and include bureaucratic, non-profit, and academic institutions (ibid.). They benefit both monetarily and socially. They are, for instance, rewarded for their adoption of the 'saviour' role (Cojocaru, 2016; Hoefinger, 2016; Steele, 2015). This role allows them to advance their careers and social status, and, in the case of NGOs, continue to receive funding from, among others, the US government (Cojocaru, 2016). One particularly overt form of this 'secondary exploitation' (Cojocaru, 2016) is described by Bernstein and Shih (2014) in their ethnographical account of a for-profit 'reality tour' organised by two anti-trafficking organisations to enable (Western) tourists to visit and explore (and be seen to condemn) the Thai sex industry.

\section{Conclusion}

As this introduction has shown, only those who fulfil a very strict set of requirements are successfully identified as victims in contemporary antitrafficking discourse. They must be female, young, preferably exploited in the sex trade, and moved without consent. This (very high) threshold means that many real victims are unrecognised, and as a result do not receive the appropriate support. In fact, they are often criminalised.

The main problem with this story is that it distracts from the structural factors that put people at risk of being trafficked, such as poverty and the global demand for cheap labour. As a result, the global West maintains its economically and ideologically dominant position and maintains existing gender norms (and thereby gender inequalities). These inequalities are, in a circular fashion, also at the root of trafficking. In short, the representation of trafficking does not aim to eradicate trafficking-it is a key factor in its perpetuation. 


\section{In THIS COLlection}

Given the contemporaneous nature of this project, the studies that follow all utilised material produced after 2000 , and material consistent with the HT definition previously outlined.

Gregoriou and Ras's chapter (Chap. 2) draws on corpus linguistic analysis of a 61.5-million-word corpus of UK news texts published during 2000-2016, and on qualitative critical discourse analysis of a 67-article sub-corpus thereof. Both approaches analyse naming strategies, metaphors, grammar, and participants' speech, though the sub-corpus analysis also engages with the accompanying images multimodally. Our findings show an over-reporting of sexual exploitation, and an insistence on victims being young, female, and vulnerable. As a result, non-stereotypical victims of crimes like forced begging and domestic servitude are not readily recognised as victims and are deprived of opportunities for assistance.

Muždeka's chapter (Chap. 3) compares the representation of transnational HT in news media texts in English and Serbian by adopting contemporary narrative, cultural, and media theory. The second chapter's UK sample corpus is here compared with a similarly compiled corpus of Serbian human trafficking news texts. It is worth comparing these two differing countries' outputs; unlike the UK, which serves as a HT destination country, Serbia serves as a country of origin, a destination country, and a key transit country in the Balkans, and lies on the route of refugees from the Middle East. Differences and similarities in representations between these two countries can highlight the roles of national politics, economics, and the realities of HT in shaping the narrative. This chapter's analysis identifies the narrative strategies (pertaining to the text, story, fabula, authorship, voice, and ideological positioning) that not only shape the news media texts but also function as a semiotic code through which reality is itself constructed. The chapter explores the construction of meaning as a socially and culturally conditioned process due to which particular aspects of transnational HT are prioritised (i.e., use of official sources), while other are neglected and/or completely excluded (i.e., victims' future), thus influencing the public perception and responses.

Beyer (Chap. 4) uses British and Scandinavian crime fiction to investigate the social implications of illegal movements of people, including Transnational Human Trafficking (THT), into Western Europe, specifically focusing on transnational child trafficking (TCT) and its representation. The inclusion of Scandinavian crime fiction in this analysis is crucial 
to its findings. Post-2000 Danish crime fiction has been actively at the forefront of treating social realist themes such as human trafficking and modern slavery (Brunsdale, 2016), and these trends extend to Swedish and British crime fiction. British and Scandinavian crime novels are employed in Beyer's analysis to demonstrate how countries, which are differently positioned geographically, are affected by HT from the Global South and in the aftermath of the fall of the Eastern Bloc, and specifically how their national crime literatures absorb and represent the theme of HT. The chapter argues that crime fiction can be seen to engage explicitly in public and private debates around HT, and effect change, and that this didactic dimension demonstrates the power of genre fiction not merely to entertain, but also importantly to heighten awareness and open up new debates.

Dearey (Chap. 5) analyses and interrogates the identities of 'traffickers' as represented within a series of television documentaries on modern slavery. The subject of analysis is specifically to depart from the UK/'Western' view or gaze and to consider the perspective from the global East/South. That this series is presented by Al Jazeera English and by a former BBC presenter who is of Muslim origin adds further dimensionality to this text. Furthermore, the types of human trafficking featured, as well as traffickers and victims, span the globe. Analysis of trafficker identities within the different typologies represented in the documentary series are shownbridal, charcoal, prison, sex, food, child, bonded slavery/trafficking. These are represented within a complex geo-cultural televisual gaze (Al Jazeera English) upon the global north/west as ultimately the source of the slavery problem.

\section{REFERENCES}

Alvarez, M. B., \& Alessi, E. J. (2012). Human trafficking is more than sex trafficking and prostitution: Implications for social work. Affilia, 27(2), 142-152.

Andrijasevic, R. (2007). Beautiful dead bodies: Gender, migration and representation in anti-trafficking campaigns. Feminist Review, 86, 24-44.

Andrijasevic, R., \& Mai, N. (2016). Editorial: Trafficking (in) representations: Understanding the recurring appeal of victimhood and slavery in neoliberal times. Anti-Trafficking Review, 7, 1-10.

Anti-Slavery International. (2014). Trafficking for forced criminal activities and begging in Europe. [Online]. Retrieved November 2016, from http:// freedomfund.org/wp-content/uploads/race_report_english.pdf 
Aronowitz, A. (2009). Human trafficking, human misery: The global trade in human beings. London: Greenwood Publishing Group.

Attwood, R. (2016). Looking beyond 'white slavery': Trafficking, the Jewish Association, and the dangerous politics of migration control in England, 1890-1910. Anti-Trafficking Review, 7, 115-138.

Avendaño, A., \& Fanning, C. (2013). Immigration policy reform in the United States: Reframing the enforcement discourse to fight human trafficking and promote shared prosperity. Anti-Trafficking Review, 2, 97-118.

Bernstein, E., \& Shih, E. (2014). The erotics of authenticity: Sex trafficking and 'reality tourism' in Thailand. Social Politics: International Studies in Gender, State and Society, 21(3), 430-460.

Brunsdale, M. M. (2016). Encyclopedia of Nordic crime fiction: Works and authors of Denmark, Finland, Norway and Sweden since 1967. Jefferson: McFarland.

Buckley, M. (2009). Public opinion in Russia on the politics of human trafficking. Europe-Asia Studies, 61(2), 213-248.

Christie, N. (1986). The ideal victim. In E. A. Fattah (ed.), From crime policy to victim policy. London: Palgrave Macmillan.

Chuang, J. (2015). The challenges and perils of reframing trafficking as 'modernday slavery'. Anti-Trafficking Review, 5, 146-149.

Clausen, C. (1982). Home and away in children's fiction. Children's Literature, $10,141-152$.

Coghlan, D., \& Wylie, G. (2011). Defining trafficking/denying justice? Forced labour in Ireland and the consequences of trafficking discourse. Journal of Ethnic and Migration Studies, 37(9), 1513-1526.

Cojocaru, C. (2016). My experience is mine to tell: Challenging the abolitionist victimhood framework. Anti-Trafficking Review, 7, 12-38.

Columb, S. (2015). Beneath the organ trade: A critical analysis of the organ trafficking discourse. Crime, Law and Social Change, 63(1), 21-47.

Cunningham, K., \& DeMarni Cromer, L. (2016). Attitudes about human trafficking: Individual differences related to belief and victim blame. Journal of Interpersonal Violence, 31(2), 228-244.

Dando, C. J., Walsh, D., \& Brierley, R. (2016). Perceptions of psychological coercion and human trafficking in the West Midlands of England: Beginning to know the unknown. PLoS ONE, 11(5), 1-13.

De Shalit, A., Heynen, R., \& Van der Meulen, E. (2014). Human trafficking and media myths: Federal funding, communication strategies, and Canadian antitrafficking programs. Canadian Journal of Communication, 39(3), 385-412.

De Villiers, N. (2016). Rebooting trafficking. Anti-Trafficking Review, (7), $161-181$.

Denton, E. (2010). International news coverage of human trafficking arrests and prosecutions: A content analysis. Women \& Criminal Justice, 20(1-2), 10-26.

Dijk, A. M. (2013). Combating human trafficking in Poland: When victims are lost in translation. Washington University Global Studies Law Review, 12(4), 783-806. 
Duong, K. A. (2014). Human trafficking in a globalized world: Gender aspects of the issue and anti-trafficking politics. Journal of Research in Gender Studies, $4(1), 788-805$.

European Commission. (2017). European civil protection and bumanitarian aid operations: Serbia, facts figures. [Online]. European Commission. Retrieved February, 11, 2017, from http://ec.europa.eu/echo/files/aid/countries/ factsheets/serbia_en.pdf

Farrell, A., \& Fahy, S. (2009). The problem of human trafficking in the U.S: Public frames and policy responses. Journal of Criminal Justice, 37(6), 617-626.

Feingold, D. A. (2005). Human trafficking. Foreign Policy, 150, 26-32.

Finnemore, M., \& Sikkink, K. (1998). International norm dynamics and political change. International Organization, 52(4), 887-917.

Galtung, J., \& Ruge, M. (1965). Structuring and selecting news. In S. Cohen \& J. Young (eds.), The manufacture of news: Social problems, deviance and the mass media (Revised ed., pp. 52-63). London: Constable.

Gould, C. (2010). Moral panic, human trafficking and the 2010 Soccer World Cup. Agenda, 24(85), 31-44.

Hall, S. L. (2015). The uncanny sacrifice: Sex trafficking in Chris Abani's Becoming Abigail. Critique-Bolingbroke Society, 56(1), 42-60.

Haynes, D. F. (2014). The celebritization of human trafficking. The Annals of the American Academy of Social and Political Science, 653(1), 25-45.

Hill, A. (2016). How to stage a raid: Police, media and the master narrative of trafficking. Anti-Trafficking Review, 7, 39-55.

Hoefinger, H. (2016). Neoliberal sexual humanitarianism and story-telling: The case of Somaly Mam. Anti-Trafficking Review, 7, 56-78.

Howard, N. (2012). Accountable to whom? Accountable for what? Understanding anti-child trafficking discourse and policy in Southern Benin. Anti-Trafficking Review, 1, 43-59.

Hua, J., \& Nigorizawa, H. (2010). US sex trafficking, women's human rights and the politics of representation. International Feminist Journal of Politics, $12(3-4), 401-423$.

Jewkes, Y. (2011). Media and crime ( $2^{\text {nd }}$ ed.). London: Sage.

Johnston, A., Friedman, B., \& Sobel, M. (2015). Framing an emerging issue: How U.S. print and broadcast news media covered sex trafficking, 2008-2012. Journal of Human Trafficking, 1(3), 235-254.

Kara, S. (2010). Sex trafficking: Inside the business of modern slavery. New York: Columbia University Press.

Kelly, L. (2005). 'You can find anything you want': A critical reflection on research on trafficking in persons within and into Europe. International Migration, $43(1-2), 235-265$.

Kinney, E. (2015). Victims, villains, and valiant rescuers: Unpacking sociolegal constructions of human trafficking and crimmigration in popular culture. In 
M. J. Guia (ed.), The illegal business of human trafficking (pp. 87-108). Cham: Springer.

Krsmanovic, E. (2016). Captured 'Realities' of human trafficking: Analysis of photographs illustrating stories on trafficking into the sex industry in Serbian media. Anti-Trafficking Review, 7, 139-160.

Lewis, H., \& Waite, L. (2015). Asylum, immigration restrictions and exploitation: Hyper-precarity as a lens for understanding and tackling forced labour. AntiTrafficking Review, 5, 50-68.

Limoncelli, S. A. (2009). The trouble with trafficking: Conceptualising women's sexual labor and economic human rights. Women's Studies International Forum, $32,261-269$.

Lobasz, J. K. (2009). Beyond border security: Feminist approaches to human trafficking. Security Studies, 18(2), 319-144.

Marchionni, D. M. (2012). International human trafficking: An agenda-building analysis of the US and British Press. International Communication Gazette, $74(2), 145-158$.

McAdam, M. (2013). Who's who at the border? A rights-based approach to identifying human trafficking at international borders. Anti-Trafficking Review, 2, $33-49$.

Mendel, J., \& Sharapov, K. (2016). Human trafficking and online networks: Policy, analysis, and ignorance. Antipode: A Radical Journal of Geography, $48(3), 665-684$.

Meshkovska, B., Mickovski, N., Bos, A. E. R., \& Siegel, M. (2016). Trafficking of women for sexual exploitation in Europe: Prosecution, trials and their impact. Anti-Trafficking Review, 6, 71-90.

Moore, A. S., \& Goldberg, E. S. (2015). Victims, perpetrators, and the limits of human rights discourse in post-Palermo fiction about sex trafficking. The International Journal of Human Rights, 19(1), 16-31.

Musto, J. L. (2009). What's in a name? Conflations and contradictions in contemporary U.S. discourses of human trafficking. Women's Studies International Forum, 32(4), 281-287.

O'Brien, E. (2016). Human trafficking heroes and villains: Representing the problem in anti-trafficking awareness campaigns. Social \& Legal Studies, 25(2), 205-224.

O'Connell Davidson, J. (2010). New slavery, old binaries: Human trafficking and the borders of 'freedom'. Global Networks, 10(2), 244-261.

O'Connell Davidson, J. (2015). Modern slavery: The margins of freedom. Basingstoke: Palgrave Macmillan.

Pajnik, M. (2010). Media framing of trafficking. International Feminist Journal of Politics, 12(1), 45-64.

Papadouka, M. E., Evangelopoulos, N., \& Ignatow, G. (2016). Agenda setting and active audiences in online coverage of human trafficking. Information, Communication o Society, 19(5), 655-672. 
Piper, N., Segrave, M., \& Napier-Moore, R. (2015). Editorial: What's in a name? Distinguishing forced labour, trafficking and slavery. Anti-Trafficking Review, $5,1-9$.

Plambech, S. (2016). The art of the possible: Making films on sex work migration and human trafficking. Anti-Trafficking Review, 7, 182-199.

Russell, A. M. (2014). Victims of trafficking: The feminisation of poverty and migration in the gendered narratives of human trafficking. Societies, 4(4), 532-548.

Sanchez, G. (2016). 'It's All in Their Brain': Constructing the figure of the trafficking victim on the US-Mexico border. Anti-Trafficking Review, 7, 97-114.

Sanford, R., Martínez, D. E., \& Weitzer, R. (2016). Framing human trafficking: A content analysis of recent U.S. newspaper articles. Journal of Human Trafficking, 2(2), 139-155.

Segrave, M. (2009). Order at the border: The repatriation of victims of trafficking. Women's Studies International Forum, 32, 251-260.

Sharma, N. (2005). Anti-trafficking rhetoric and the making of a global apartheid. NWSA Journal, 17, 88-111.

Small, J. L. (2012). Trafficking in truth: Media, sexuality, and human rights evidence. Feminist Studies, 38(2), 415-443.

Snajdr, E. (2013). Beneath the master narrative: Human trafficking, myths of sexual slavery and ethnographic realities. Dialectical Anthropology, 37(2), 229-256.

Sobel, M. R. (2014). Chronicling a crisis: Media framing of human trafficking in India, Thailand, and the USA. Asian Journal of Communication, 24(4), 315-332.

Sobel, M. R. (2016). Confronting sex trafficking: Gender depictions in newspaper coverage from the former Soviet republics and the Baltic states. European Journal of Communication, 31(2), 152-168.

Steele, S. L. (2015). Real and unreal masculinities: The celebrity image in antitrafficking campaigns. Journal of Gender Studies, 24(4), 419-435.

Stepnitz, A. (2012). A lie more disastrous than the truth: Asylum and the identification of trafficked women in the UK. Anti-Trafficking Review, 1, 104-121.

Szörényi, A. (2016). Expelling slavery from the nation: Representations of labour exploitation in Australia's supply chain. Anti-Trafficking Review, 7, 79-96.

Szörényi, A., \& Eate, P. (2014). Saving virgins, saving the USA: Heteronormative masculinities and the securitisation of trafficking discourse in mainstream narrative film. Social Semiotics, 24(5), 608-622.

Van der Pijl, Y., Oude Breuil, B. C., \& Siegel, D. (2011). Is there such thing as 'global sex trafficking'? A patchwork tale on useful (mis)understandings. Crime, Law and Social Change, 56(5), 567-582.

Weitzer, R. (2007). The social construction of sex trafficking: Ideology and institutionalisation of a moral crusade. Politics and Society, 35, 447-475.

Wijers, M. (2015). Purity, victimhood and agency: Fifteen years of the UN trafficking protocol. Anti-Trafficking Review, 4, 56-79. 
Wilson, M., \& O'Brien, E. (2016). Constructing the ideal victim in the United States of America's annual trafficking in persons reports. Crime, Law and Social Change, 65(1), 29-45.

Winterdyk, J., Reichel, P., \& Perrin, B. (eds.). (2012). Human trafficking: Exploring the international nature, concerns, and complexities. Boca Raton: CRC Press.

Wylie, G. (2016). The international politics of human trafficking. London: Palgrave.

Yick, A. G. (2010). Social construction of human trafficking on YouTube: An exploratory study. Journal of Immigrant \& Refugee Studies, 8(1), 11-16.

Open Access This chapter is licensed under the terms of the Creative Commons Attribution 4.0 International License (http://creativecommons.org/licenses/ by $/ 4.0 /)$, which permits use, sharing, adaptation, distribution and reproduction in any medium or format, as long as you give appropriate credit to the original author(s) and the source, provide a link to the Creative Commons license and indicate if changes were made.

The images or other third party material in this chapter are included in the chapter's Creative Commons license, unless indicated otherwise in a credit line to the material. If material is not included in the chapter's Creative Commons license and your intended use is not permitted by statutory regulation or exceeds the permitted use, you will need to obtain permission directly from the copyright holder.

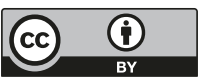

